\title{
Late Effects of Disturbed IGF Signaling in Congenital Diseases
}

\section{Intrauterine and Postnatal Growth Retardation}

\author{
Stefano Cianfarani, Caterina Geremia, Antonella Puglianiello, \\ Arianna Maiorana, Daniela Germani
}

Rina Balducci Center of Pediatric Endocrinology, Department of Public Health and Cell Biology, Tor Vergata University, Rome, Italy

\footnotetext{
Abstract

The biologic effects of insulin-like growth factor-1 (IGF-1) are mediated by specific cell surface receptors. IGF-1 binding to the extracellular $\alpha$-subunits activates the tyrosine kinase intrinsic to the cytoplasmic portion of the IGF-1 receptor, leading to autophosphorylation of specific tyrosine residues in the receptor $\beta$-subunit. One early molecular event that links the receptor kinase to the biologic actions of IGF-1 is tyrosine phosphorylation of the insulin receptor substrate family (IRS-1 to -4). IRS acts as a multisite 'docking' protein by binding to downstream signal-transducing molecules. Phosphorylation of multiple tyrosine residues results in the association of IRS-1 with the Src homology 2 (SH2) domains of other cytoplasmic signaling proteins, including phosphatidylinositol 3' kinase, Syp, Grb2 and Nck. By binding to Grb2, IRS proteins couple the IGF-1 receptor to the Ras/mitogenactivated protein kinase pathway. This pathway regulates cell growth, differentiation and proliferation. Severe pre- and postnatal growth retardation may arise from abnormalities of IGF-1 signaling such as IGF-1-binding alterations and IGF-1 receptor mutations. Knockout studies have shown severe growth impairment in mice lacking IRS family components or Akt. Finally, in human placentas from pregnancies complicated by intrauterine growth retardation, multiple alterations of IGF-1-signaling molecules have recently been described.

Copyright (C) 2007 S. Karger AG, Basel

\section{Structure of the Insulin and IGF-1 Receptors}

Insulin and insulin-like growth factor-1 (IGF-1) are peptide hormones that are homologous in primary structure but differ in their physiological effects. Insulin and IGF-1 exert their biological effects by binding to their respective
} 


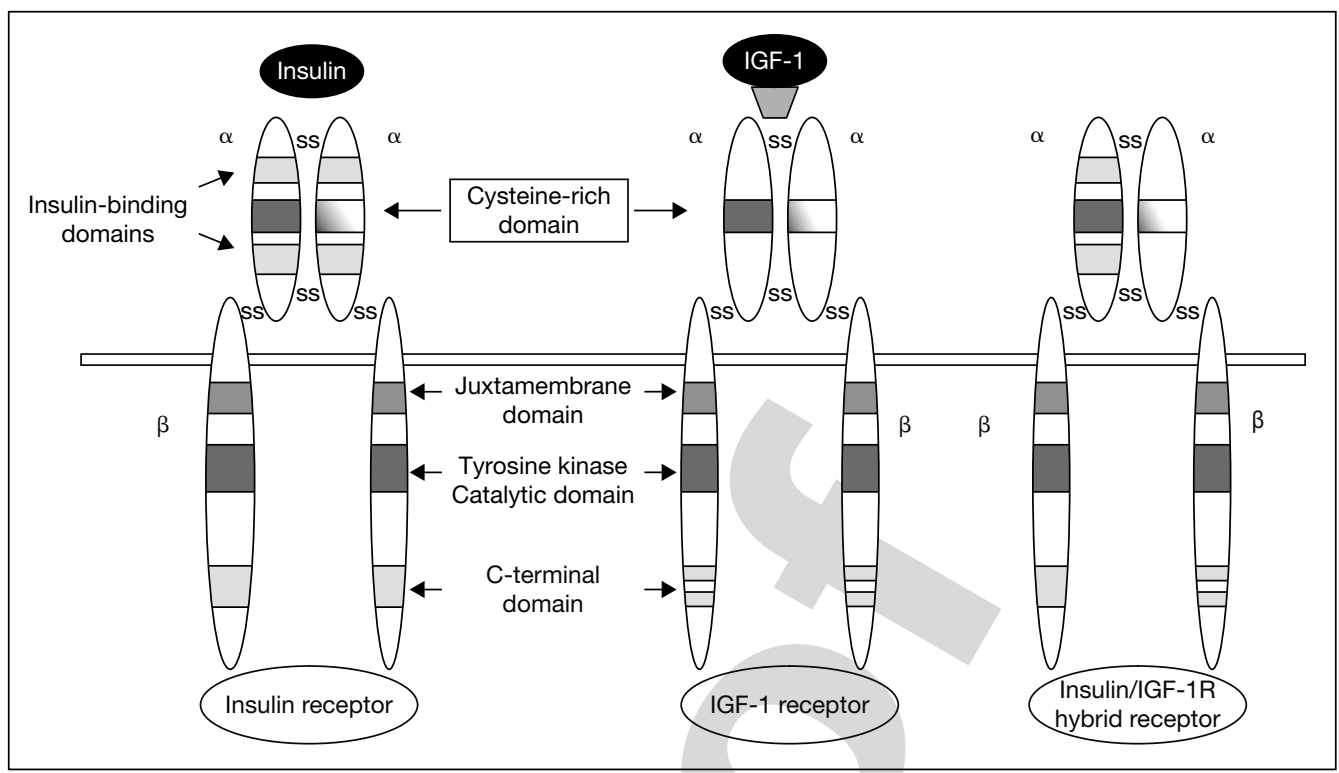

Fig. 1. The IGF family of ligands and receptors (IGF-1R). Modified from Dupont et al. [1].

receptors, the insulin receptor (IR) and the IGF-1 receptor (IGF-1R). The IR and IGF-1R have similar molecular weights, and both have tyrosine kinase activity. The IR and IGF-1R are both comprised of 2 extracellular $\alpha$-subunits containing ligand-binding sites and 2 transmembrane $\beta$-subunits transmitting the ligandinduced signal [1,2]. More specifically, IGF-1R and IR $\beta$-subunits consist of 3 domains: (1) a juxtamembrane domain, with motifs required for recruiting the major signaling adapter proteins; (2) a tyrosine kinase domain, essential for catalytic activity of the receptor, and (3) the carboxyl-terminal domain, which has several important residues for IGF-1R and IR signaling (fig. 1).

Despite the structural similarities between IGF-1 and insulin, the IR and IGF-1R have a 100- to 1,000-fold higher binding affinity for their cognate ligands. The $\alpha$-subunits have been shown to confer ligand-binding specificity [3].

Structural differences in the cytoplasmic domain of the $\beta$-subunits of the IR and IGF-1R may contribute to the divergence of these 2 signaling pathways. The highest degree of homology between the 2 receptors is found within the tyrosine kinase domain (about $84 \%$ ), whereas the region of greatest divergence between the IR and IGF-1R is found within the juxtamembrane domain (about $61 \%$ ) and the carboxyl-terminal domain (about 56\%) $[4,5]$. 


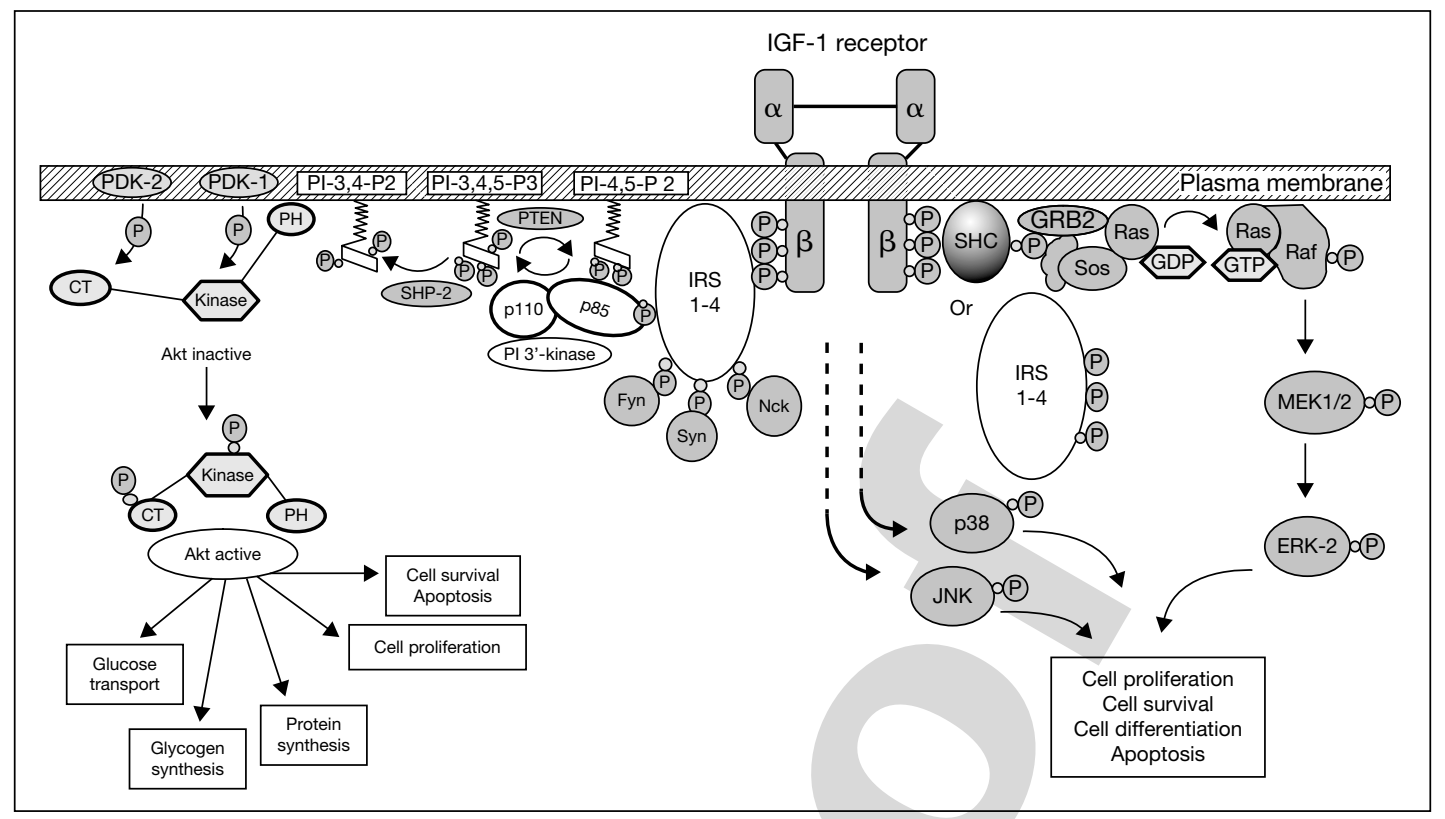

Fig. 2. Multiple signaling pathways for the IGF-1R. ERK = Extracellular signalregulated kinase; $\mathrm{MEK}=$ mitogen extracellular kinase; $\mathrm{JNK}=$ Jun kinase; $\mathrm{CT}=$ carboxyterminal; GDP = guanosine diphosphate; GTP = guanosine triphosphate; $\mathrm{PDK}=$ phosphoinositide-dependent kinase; $\mathrm{PH}=$ pleckstrin homology domain; $\mathrm{PI}=$ phosphatidylinositol; PTEN = phosphatase and tensin homologue; $\mathrm{SHC}=\mathrm{Src}$ homology collagen; SHP $=$ Src homology phosphatase. Modified from Dupont et al. [1].

\section{Signal Transduction via Insulin Receptor and IGF-1 Receptor}

Many of the intracellular signaling events mediated by activation of the IR and IGF-1R are remarkably similar [6-8]. Some of the shared substrates that become phosphorylated by the IGF-1R and IR include members of the insulin receptor substrate (IRS) family of proteins (IRS-1, -2, -3 and -4) [9-12], Gab-1 [13], and Shc [14]. The ability of phosphorylated soluble proteins, such as the IRS family, to bind Src-homology-2-containing proteins may provide a way to relay a signal from a receptor anchored in the plasma membrane to other cellular compartments. Upon stimulation by insulin or IGF-1, tyrosine-phosphorylated IRS and She proteins form signaling complexes between phosphotyrosinecontaining binding motifs and Src homology 2 domains found in molecules such as growth factor receptor binding-2 protein $(\mathrm{Grb} 2)[15,16]$ and the $\mathrm{p} 85$ regulatory subunit of the phosphatidylinositol 3' kinase [17] and Syp (a tyrosine phosphatase) [18] (fig. 2). Binding of phosphatidylinositol $3^{\prime}$ kinase to 
phosphorylated IRS leads to a 10-fold stimulation of its activity, accounting for the rapid rise in phosphorylated phosphatidylinositols in stimulated cells. Binding of Grb2 to IRS and the subsequent binding of Grb2 (an adapter protein) to Sos protein may account for the increase in the proportion of the active Ras-GTP complex, which in turn leads to activation of mitogen-activated protein kinase (MAPK) cascade (fig. 2). Binding of Syp to IRS causes a marked increase in its tyrosine phosphatase activity. Activated Syp may dephosphorylate IRS, thereby terminating signaling. The phosphotyrosine residues on IRS-1 also form docking sites for other signaling molecules, including Fyn [19], Nck [20] and Crk [21]. By binding to Grb2, the Ras/MAPK pathway regulates cell growth, differentiation and proliferation in response to insulin and IGF-1 [22, 23]. Various protein tyrosine phosphatases can regulate the activities of the IR and IGF-1R signaling systems. The specificity of signaling may be explained by the preferential use of different substrates by the IR and IGF-1R [24]. In particular, the IR couples preferentially to IRS-2, whereas the IGF-1R couples preferentially to IRS-1. This conclusion has been confirmed by ablation of the $I R S-1$ and IRS-2 genes in mice [25-27].

\section{Altered Ligand-Receptor Interaction: Missense Mutation in the IGF-1 Gene}

In mice, the growth-hormone-IGF-1 system plays a key role in intrauterine development and postnatal growth and metabolism [28-30]. Knockout models of the growth hormone receptor and IGF-1 have indicated that in utero IGF-1, but not growth hormone, is required for normal fetal growth $[28,30,31]$.

Walenkamp et al. [32] recently described a 55-year-old patient, the first child of consanguineous parents, presenting with severe intrauterine and postnatal growth retardation, microcephaly and sensorineural deafness. A homozygous $\mathrm{G}$ to A nucleotide substitution in the $I G F-1$ gene changing valine 44 into methionine was found. The inactivating nature of the mutation was proven by functional analysis. Proof for the inactivating nature of V44M was provided by demonstrating a 90-fold lower binding affinity for the IGF-1R in receptorbinding assays using recombinantly produced protein. Additional investigations revealed osteoporosis, a partial gonadal dysfunction and a relatively wellpreserved cardiac function. The phenotype of this patient was caused by a complete lack of bioactive IGF-1. IGF-2, although in the upper normal range, was not able to compensate for IGF-1 deficiency in utero, in childhood and neither in adulthood. Nine of the 24 relatives studied carried the mutation. They had a 
significantly lower birth weight, final height and head circumference than noncarriers.

\section{IGF-1 Receptor Mutations}

Since deletion of the murine $I G F-1 R$ gene causes marked prenatal growth failure (birth weight, $45 \%$ of normal weight), with the affected neonates dying from respiratory depression, the complete absence of IGF-1Rs in humans would be expected to cause severe disease and perhaps be lethal. However, less severe perturbations might attenuate the phenotype, as do naturally occurring missense mutations in the $I R$ gene that cause moderate insulin resistance.

Abuzzahab et al. [33] screened 2 groups of children for abnormalities in the IGF-1R gene: (a) a group of 42 patients with unexplained intrauterine growth retardation and subsequent short stature, and (b) a second cohort consisted of 50 children with short stature who had elevated circulating IGF-1 concentrations. In the first cohort, 1 girl who was a compound heterozygote for point mutations in exon 2 of the $I G F-1 R$ gene that altered the amino acid sequence to Arg108Gln in one allele and Lys115Asn in the other was found. Fibroblasts cultured from the patient had decreased IGF-1R function, as compared with that in control fibroblasts. In the second group, 1 boy with a nonsense mutation (Arg59stop) that reduced the number of IGF-1R on fibroblasts was identified. Both children had intrauterine growth retardation and poor postnatal growth.

Kawashima et al. [34] identified a heterozygous mutation (R709Q) changing the cleavage site from Arg-Lys-Arg-Arg to Arg-Lys-Gln-Arg in a 6-year-old Japanese girl (case 1) and her mother, who also showed intrauterine growth restriction (IUGR) with short stature (case 2). Furthermore, (a) fibroblasts from case 2 contained more IGF-1R proreceptor protein and less mature $\beta$-subunit protein; (b) [125I]IGF-1 binding to fibroblasts from case 2 was reduced, compared with normal controls, and (c) both IGF-1-stimulated $\left[{ }^{3} \mathrm{H}\right]$ thymidine incorporation and IGF-1R $\beta$-subunit autophosphorylation were low in fibroblasts from case 2, compared with those of controls. These findings strongly suggest that this mutation leads to failure of processing of the IGF-1R proreceptor to mature IGF-1R, causing short stature and IUGR.

More recently, Walenkamp et al. [35] described a 35-year-old female with mild intrauterine growth failure, progressive postnatal growth retardation, severe failure to thrive and microcephaly. Her daughter was born with severe intrauterine growth retardation and also showed postnatal failure to thrive and microcephaly. A heterozygous G31483A nucleotide substitution in the $I G F-1 R$ gene, changing a negatively charged glutamic acid at position 1050 into a 
Table 1. Clinical features of the 4 families with heterozygous IGF-1R mutations, modified from Walenkamp et al. [35]

\begin{tabular}{lllllll}
\hline No. & Subject & Mutation & $\begin{array}{l}\text { Birth } \\
\text { weight }\end{array}$ & $\begin{array}{l}\text { Birth } \\
\text { length }\end{array}$ & $\begin{array}{l}\text { Head } \\
\text { circumference }\end{array}$ & $\begin{array}{l}\text { Last } \\
\text { reported } \\
\text { height }\end{array}$ \\
\hline 1A & index case & R108Q & -3.5 & & -4.8 \\
1B & mother & K115N & K115N & -2.0 & & \\
1C & father & R108Q & -2.0 & & & -1.6 \\
2A & index case & R59stop & -3.5 & -5.8 & -4.6 at birth & -2.6 \\
2B & brother & R59stop & -2.7 & -2.1 & & -2.6 \\
2C & mother & R59stop & -2.4 & -1.6 & & -2.1 \\
3A & index case & R709Q & -1.5 & -1.0 & & -2.9 \\
3B & mother & R709Q & -1.6 & & -4.0 \\
4A & mother & E1050K & -2.1 & -0.3 & -3.0 at 35 years & -2.3 \\
4B & daughter & E1050K & -3.3 & -4.2 & -5.6 at 2 months & -2.3 \\
\hline
\end{tabular}

Families 1 and 2 were described by Abuzzahab et al. [33], family 3 by Kawashima et al. [34] and family 4 by Walenkamp et al. [35]. Data are expressed as SDS.

positively charged lysine residue (E1050K) was found. E1050 is a conserved residue in the intracellular kinase domain. The patients had a mutation in exon 16 , coding for the intracellular tyrosine kinase domain of the receptor. The tyrosine kinase (catalytic) domain is part of the cytoplasmic portion of the $\beta$-chain of the IGF-1R. Binding of IGF-1 to the extracellular $\alpha$-chain induces a conformational change in the structure of the receptor, leading to autophosphorylation of 3 tyrosines in the activation loop of the catalytic domain of the $\beta$-chain. Phosphorylation of the tyrosine residues results in a dramatic conformational change. Dermal fibroblasts of the mother showed normal binding of iodinated IGF-1, but autophosphorylation and activation of downstream signaling cascades upon challenging with IGF-1 was markedly reduced. The mutation affecting the intracellular portion of IGF-1R caused IGF-1 insensitivity as shown by the dramatic reduction of the fibrobast $\left[{ }^{3} \mathrm{H}\right]$ thymidine incorporation upon challenge with a dose range of IGF-1.

It is noteworthy that these patients with defects in the $I G F-1 R$ gene were not phenotypically identical (table 1). The reasons for these differences are not evident but could reflect differences in the intensity of IGF-1 signaling among these patients, since the $I G F-1 R$ mutations blunt but do not abrogate IGF-1 signaling. The phenotypic differences may also be explained by tissue-specific imprinting of the expression of the $I G F-1 R$ alleles. 
In the human, the $I G F-1 R$ gene is located on the distal long arm of chromosome $15(15 \mathrm{q} 26.3)$. The receptor is synthesized as a large precursor protein that undergoes extensive posttranslational modifications including cleavage and glycosylation. Monoallelic loss of chromosome $15 \mathrm{q}$ and loss of 1 copy of the $I G F-1 R$ gene due to deletions of the distal long arm of chromosome 15 have been found in patients with intrauterine growth retardation and postnatal growth deficit [36, 37].

In a tall child with 3 copies of the $I G F-1 R$ gene, accelerated growth was ascribed to overactivation of the receptor kinase resulting from increased binding of the ligand [38]. It was concluded that hemizygosity for $I G F-1 R$ can cause primary IGF-1 resistance. Patients with loss of material from the distal arm of chromosome 15 show intrauterine growth retardation, postnatal growth deficits, occasionally craniofacial and skeletal abnormalities and mild to moderate mental retardation [36].

\section{IGF-1 Signaling Alterations}

The activated receptors for insulin and IGF-1 phosphorylate various cellular substrates, including IRS-1 and IRS-2, which integrate the pleiotropic effects of insulin, IGF-1 and other cytokines on cellular function. Deletion of Irs 1 produces small, insulin-resistant mice with nearly normal glucose homeostasis due to compensatory $\beta$-cell expansion [39]. In contrast, mice lacking IRS-2 display nearly normal growth but develop diabetes 8-10 weeks after birth accompanied by reduced $\beta$-cell mass and impaired function [40].

IRS-1 and IRS-2 mediate the effects of insulin and IGF-1 on embryonic development, postnatal somatic growth and glucose homeostasis. IRS-1 has a predominant role in somatic growth, as deletion of Irs 1 reduces embryonic and neonatal growth by $40 \%$, whereas deletion of $\operatorname{Irs} 2$ reduces growth by $10 \%$. Irs $1+/-I r s 2-1-$ mice are approximately $60 \%$ the size of wild-type animals, whereas Irs $1-/-\operatorname{Irs} 2+/-$ mice are only $30 \%$ the size of controls, implicating IRS-1 as the principal element by which IGF-1 mediates somatic growth [41].

The serine-threonine kinase Akt, also known as protein kinase B (PKB), is an important effector for phosphatidylinositol $3^{\prime}$ kinase signaling initiated by numerous growth factors and hormones. Akt2/PKB $\beta, 1$ of 3 known mammalian isoforms of Akt/PKB, was recently demonstrated to be required for at least some of the metabolic actions of insulin. Cho et al. [42] showed that mice deficient in another closely related isoform of the kinase, $\mathrm{Akt} 1 / \mathrm{PKB} \alpha$, display a conspicuous impairment in growth. Akt1-/- mice demonstrated defects in both fetal and postnatal growth, and these persisted into adulthood. Akt1 - / - animals were distinguishable from wild-type animals because of their smaller size. Examination of Akt1/PKB $\alpha$-deficient mice at birth revealed an $\sim 20 \%$ reduction in body 
weight in comparison with wild-type mice, suggesting that reduction in size occurs during embryonic development. The decrease in body weight was evident throughout postnatal development, regardless of sex, and persisted into adulthood. However, in striking contrast to Akt2/PKB $\beta$ null mice, Akt1/PKB $\alpha$-deficient mice are normal with regard to glucose tolerance and insulin-stimulated disposal of blood glucose. Thus, the characterization of the Akt 1 knockout mice and its comparison to the previously reported $A k t 2$-deficiency phenotype revealed the nonredundant functions of $A k t 1$ and $A k t 2$ genes with respect to growth and insulin-regulated glucose metabolism [42].

\section{IGF-1 Signaling Alterations in Human Placentas with Intrauterine Growth Restriction}

IGFs promote growth and development of the fetoplacental unit during gestation [43], and impairment of their placental actions may result in altered intrauterine growth of the fetus. Laviola et al. [44] investigated IGF-1 signaling in human placentas from pregnancies complicated by IUGR. Placental tissue was removed immediately after delivery and analyzed by immunoprecipitation and immunoblotting techniques to study multiple signaling molecules involved in IGF-1 regulation of growth and differentiation.

IUGR placentas exhibited a 33\% reduction in the protein content of IGF1 Rs but no changes in IR protein levels. In addition, IRS-2 protein levels were reduced in IUGR placentas, with no changes in IRS-1 or Shc protein content, and this was associated with a parallel decrease in IRS-2-associated phosphatidylinositol 3' kinase.

Akt protein expression was also reduced in IUGR, whereas phosphorylation of Akt and its substrate glycogen synthase kinase-3 was unchanged. Finally, in IUGR placentas there was impaired activation of multiple members of the MAPK family, because phosphorylation of p38 and c-Jun N-terminal kinase was reduced by $70 \%$.

Targeted disruption of the p38 MAPK gene results in homozygous embryonic lethality because of severe defects in placental development. In particular, p38 mutant placentas display impaired vascularization and insufficient oxygen and nutrient transport as well as increased rates of apoptosis, consistent with a defect in placental angiogenesis $[45,46]$. In primary human trophoblast, specific activation of Jun kinase in response to placental growth factor protects from serum-withdrawal-induced apoptosis [47]. Reduced activation of Jun kinase has also been observed in placental tissue from women with pre-eclampsia [48], which features a defective vascular development of the fetoplacental unit, similar to IUGR pregnancies [49]. 


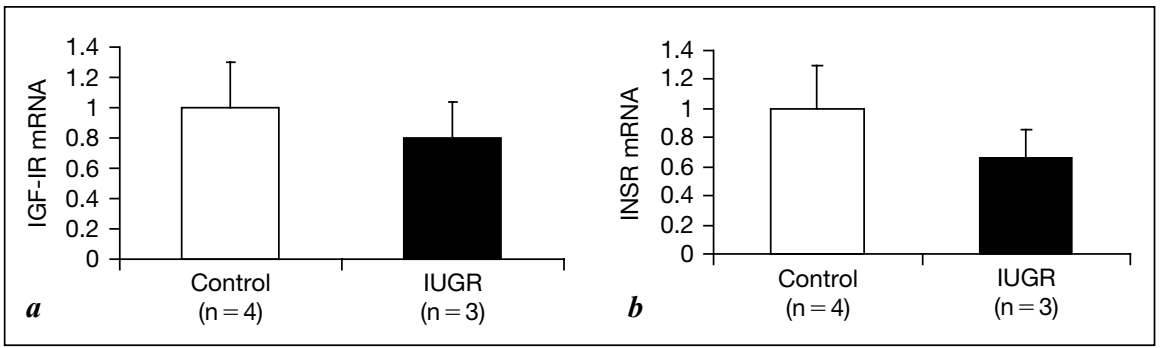

Fig. 3. RT-PCR analysis of IGF-1 (a) and IR (b) mRNA expression in human cytotrophoblasts of placentas from pregnancies complicated by intrauterine growth retardation and controls. mRNA expression indicated as

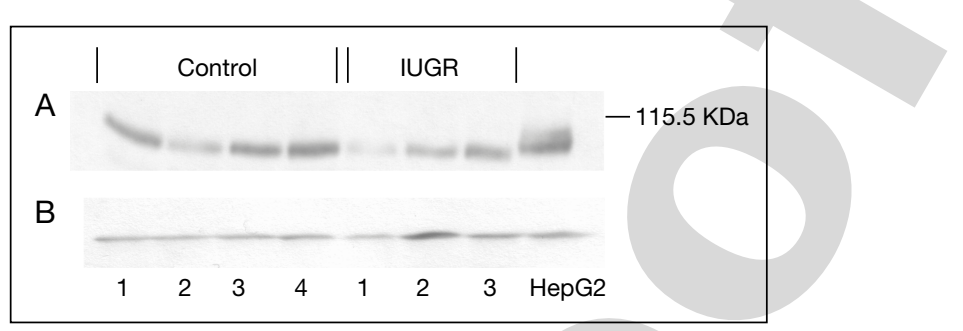

Fig. 4. Western immunoblotting for IR protein in human cytotrophoblasts of placentas from pregnancies complicated by intrauterine growth retardation and controls.

Together, these findings strongly support the hypothesis that the impairment in the integrated activation of the MAPKs observed in IUGR placentas may play an important role in altering placental angiogenesis, ultimately leading to reduced fetal growth. The human syncytial trophoblast is known to serve several roles in pregnancy. It mediates the transport of nutrients and immunoglobulins from the maternal to the fetal circulation and also functions as an endocrine organ, secreting steroid and protein hormones [50]. Syncytial trophoblast has been proposed to derive from mononuclear cytotrophoblasts undergoing a process of differentiation and fusion, or, alternatively, endomitosis (i.e. nuclear division without cytokinesis).

We recently applied a method to generate purified human cytotrophoblasts from human term placentas by adding a Percoll gradient centrifugation step to a standard trypsin-DNase dispersion method [50]. Viability was greater than $90 \%$. We investigated the expression of IGF-1 and IRs in pregnancies complicated by intrauterine growth retardation. Preliminary data suggest that whilst IGF-1R expression is unaltered, IR mRNA and protein expression seems to be impaired in cytotrophoblasts from IUGR placentas (figs 3, 4). 


\section{References}

1 Dupont J, Dunn SE, Berrett JC, Leroith D: Microarray analysis and identification of novel molecules involved in insulin-like growth factor-1 receptor signalling and gene expression. Rec Prog Horm Res 2003;58:325-342.

2 Yarden Y, Ullrich A: Molecular analysis of signal transduction by growth factors. Biochemistry 1988;27:3113-3119.

3 Schumacher R, Mosthaf L, Schlessinger J, Brandenburg D, Ullrich A: Insulin and insulin-like growth factor-1 binding specificity is determined by distinct regions of their cognate receptors. J Biol Chem 1991;266:19288-19295.

4 Ullrich A, Gray A, Tam AW, Yang-Feng T, Tsubokawa M, Collins C, Henzel W, Le Bon T, Kathuria S, Chen E: Insulin-like growth factor I receptor primary structure: comparison with insulin receptor suggests structural determinants that define functional specificity. EMBO J 1986;5:2503-2512.

5 Ullrich A, Schlessinger J: Signal transduction by receptors with tyrosine kinase activity. Cell 1990;61:203-212.

6 White MF: The IRS-1 signalling system. Curr Opin Genet Dev 1994;4:47-54.

7 Cheatham B, Kahn CR: Insulin action and the insulin signalling network. Endocr Rev 1995;16 117-142.

8 LeRoith D, Werner H, Beitner-Johnson D, Roberts CT Jr: Molecular and cellular aspects of the insulin-like growth factor I receptor. Endocr Rev 1995;16:143-163.

9 Sun XJ, Pons S, Asano T, Myers MG Jr, Glasheen E, White MF: The Fyn tyrosine kinase binds IRS-1 and forms a distinct signalling complex during insulin stimulation. J Biol Chem 1996;271: 10583-10587.

10 Lavan BE, Lienhard GE: The insulin-elicited 60-kDa phosphotyrosine protein in rat adipocytes is associated with phosphatidylinositol 3-kinase. J Biol Chem 1993;268:5921-5928.

11 Patti ME, Sun XJ, Bruening JC, Araki E, Lipes MA, White MF, Kahn CR: 4PS/insulin receptor substrate (IRS)-2 is the alternative substrate of the insulin receptor in IRS-1-deficient mice. J Biol Chem 1995;270:24670-24673.

12 Fantin VR, Sparling JD, Slot JW, Keller SR, Lienhard GE, Lavan BE: Characterization of insulin receptor substrate 4 in human embryonic kidney 293 cells. J Biol Chem 1998;273: 10726-10732.

13 Winnay JN, Bruning JC, Burks DJ, Kahn CR: Gab-1-mediated IGF-1 signalling in IRS-1deficient 3T3 fibroblasts. J Biol Chem 2000;275:10545-10550.

14 Pelicci G, Lanfrancone L, Grignani F, McGlade J, Cavallo F, Forni G, Nicoletti I, Pawson T, Pelicci PG: A novel transforming protein (SHC) with an $\mathrm{SH} 2$ domain is implicated in mitogenic signal transduction. Cell 1992;70:93-104.

15 Lowenstein EJ, Daly RJ, Batzer AG, Li W, Margolis B, Lammers R, Ullrich A, Skolnik EY, BarSagi D, Schlessinger J: The SH2 and SH3 domain-containing protein GRB2 links receptor tyrosine kinases to ras signalling. Cell 1992;70:431-442.

16 Skolnik EY, Lee CH, Batzer A, Vicentini LM, Zhou M, Daly R, Myers MJ Jr, Backer JM, Ullrich A, White MF: The SH2/SH3 domain-containing protein GRB2 interacts with tyrosine-phosphorylated IRS1 and Shc: implications for insulin control of ras signalling. EMBO J 1993;12:1929-1936.

17 Backer JM, Myers MG Jr, Shoelson SE, Chin DJ, Sun XJ, Miralpeix M, Hu P, Margolis B, Skolnik EY, Schlessinger J: Phosphatidylinositol 3'-kinase is activated by association with IRS-1 during insulin stimulation. EMBO J 1992;11:3469-3479.

18 Xiao S, Rose DW, Sasaoka T, Maegawa H, Burke TR Jr, Roller PP, Shoelson SE, Olefsky JM: Syp (SH-PTP2) is a positive mediator of growth factor-stimulated mitogenic signal transduction. J Biol Chem 1994;269:21244-21248.

19 Sun XJ, Pons S, Asano T, Myers MG Jr, Glasheen E, White MF: The Fyn tyrosine kinase binds IRS-1 and forms a distinct signalling complex during insulin stimulation. J Biol Chem 1996;271: $10583-10587$.

20 Lee CH, Li W, Nishimura R, Zhou M, Batzer AG, Myers MG Jr, White MF, Schlessinger J, Skolnik EY: Nck associates with the SH2 domain-docking protein IRS-1 in insulin-stimulated cells. Proc Natl Acad Sci USA 1993;90:11713-11717. 
21 Beitner-Johnson D, Blakesley VA, Shen-Orr Z, Jimenez M, Stannard B, Wang LM, Pierce J, LeRoith D: The proto-oncogene product c-Crk associates with insulin receptor substrate-1 and 4PS: modulation by insulin growth factor-I (IGF) and enhanced IGF-I signalling, J Biol Chem 1996;271:9287-9290.

22 Blenis J: Signal transduction via the MAP kinases: proceed at your own RSK. Proc Natl Acad Sci USA 1993;90:5889-5892.

23 Crews CM, Erikson RL: Extracellular signals and reversible protein phosphorylation: what to Mek of it all. Cell 1993;74:215-217.

24 Rother KI, Imai Y, Caruso M, Beguinot F, Formisano P, Accili D: Evidence that IRS-2 phosphorylation is required for insulin action in hepatocytes. J Biol Chem 1998;273:17491-17497.

25 Araki E, Lipes MA, Patti ME, Bruning JC, Haag B III, Johnson RS, Kahn CR: Alternative pathway of insulin signalling in mice with targeted disruption of the IRS-1 gene. Nature 1994;372: 186-190.

26 Tamemoto H, Kadowaki T, Tobe K, Yagi T, Sakura H, Hayakawa T, Terauchi Y, Ueki K, Kaburagi Y, Satoh S, Sekihara H, Yoshioka S, Horikoshi H, Furuta Y, Ikawa Y, Kasuga M, Yazaki Y, Aizawa S: Insulin resistance and growth retardation in mice lacking insulin receptor substrate-1. Nature 1994;372:182-186.

27 Withers DJ, Gutierrez JS, Towery H, Burks DJ, Ren JM, Previs S, Zhang Y, Bernal D, Pons S, Shulman GI, Bonner-Weir S, White MF: Disruption of IRS-2 causes type 2 diabetes in mice. Nature 1998;391:900-904.

28 Baker J, Liu JP, Robertson EJ, Efstratiadis A: Role of insulin-like growth factors in embryonic and postnatal growth. Cell 1993;75:73-82.

29 Liu JP, Baker J, Perkins AS, Robertson EJ, Efstratiadis A: Mice carrying null mutations of the genes encoding insulin-like growth factor I (Igf-1) and type 1 IGF receptor (Igf1r). Cell 1993;75: 59-72.

30 Powell-Braxton L, Hollingshead P, Warburton C, Dowd M, Pitts-Meek S, Dalton D, Gillett N, Stewart TA: IGF-I is required for normal embryonic growth in mice. Genes Dev 1993;7: 2609-2617.

31 Lupu F, Terwilliger JD, Lee K, Segre GV, Efstratiadis A: Roles of growth hormone and insulin-like growth factor 1 in mouse postnatal growth. Dev Biol 2001;229:141-162.

32 Walenkamp MJE, Karperien M, Pereira AM, Hilhorst-Hofstee Y, van Doorn J, Chen JW, Mohan S, Denley A, Forbes B, van Duyvenvoorde HA, van Thiel SW, Sluimers CA, Bax JJ, de Laat JAPM, Breuning MB, Romijn JA, Wit JM: Homozygous and heterozygous expression of a novel insulinlike growth factor-I mutation. J Clin Endocrinol Metab 2005;90:2855-2864.

33 Abuzzahab MJ, Schneider A, Goddard A, Grigorescu F, Lautier C, Keller E, Kiess W, Klammt J, Kratzsch J, Osgood D, Pfäffle R, Raile K, Seidel B, Smith RJ, Chernausek SD: IGF-I receptor mutations resulting in intrauterine and postnatal growth retardation. N Engl J Med 2003;349: 2211-2222.

34 Kawashima Y, Kanzaki S, Yang F, Kinoshita T, Hanaki K, Nagaishi Ji, Ohtsuka Y, Hisatome I, Ninomoya H, Nanba E, Fukushima T, Takahashi SI: Mutation at cleavage site of insulin-like growth factor receptor in a short-stature child born with intrauterine growth retardation. J Clin Endocrinol Metab 2005;90:4679-4687.

35 Walenkamp MJE, van der Kamp HJ, Pereira AM, Kant SG, van Duyvenvoorde HA, Kruithof MF, Breuning MH, Romijn JA, Karperien M, Wit JM: A variable degree of intrauterine and postnatal growth retardation in a family with a missense mutation in the insulin-like growth factor I receptor. J Clin Endocrinol Metab 2006;91:3062-3070.

36 Kiess W, Kratzsch J, Keller E, Schneider A, Raile K, Klammt J, Seidel B, Garten A, Schmidt H, Pfäffle R: Clinical examples of disturbed IGF signalling: intrauterine and postnatal growth retardation due to mutations of the insulin-like growth factor I receptor (IGF-IR) gene. Rev Endocr Metab Disord 2005;6:183-187.

37 Roback EW, Barakt AJ, Dev VG, Mbikay M, Chretien M, Butler MG: An infant with deletion of the distal long arm of chromosome 15 (q26.1-qter) and loss of IGF-I receptor gene. Am J Med Genet 1991;38:74-79.

38 Nagai T, Shimokawa O, Harada N, Sakazume S, Ohashi H, Matsumoto N, Obata K, Yoshino A, Murakami N, Murai T, Sakuta R, Niikawa N: Postnatal overgrowth by 15q-trisomy and intrauterine 
growth retardation by $15 \mathrm{q}-$ monosomy due to familial translocation $\mathrm{t}(13 ; 15)$ : dosage effect of IGF-IR? Am J Med Genet 2002;113:173-177.

39 Tamemoto H, Kadowaki T, Tobe K, Yagi T, Sakura H, Hayakawa T, Terauchi Y, Ueki K, Kaburagi Y, Satoh S, Sekihara H, Yoshioka S, Horikoshi H, Furuta Y, Ikawa Y, Kasuga M, Yazaki Y, Aizawa S: Insulin resistance and growth retardation in mice lacking insulin receptor substrate-1. Nature 1994;372:182-186.

40 Withers DJ, Gutierrez JS, Towery H, Burks DJ, Ren JM, Previs S, Zhang Y, Bernal D, Pons S, Shulman GI, Bonner-Weir S, White MF: Disruption of IRS-2 causes type 2 diabetes in mice. Nature 1998;391:900-903.

41 Withers DJ, Burks DJ, Towery HH, Altamuro SL, Flint CL, White MF: IRS-2 coordinates Igf-1 receptor-mediated $\beta$-cell development and peripheral insulin signalling. Nature 1999;23:32-40

42 Cho H, Thorvaldsen JL, Chu Q, Feng F, Birnbaum MJ: Akt1/PKB $\alpha$ is required for normal growth but dispensable for maintenance of glucose homeostasis in mice. J Biol Chem 2001;42: 38349-38352.

43 Fowden AL: The insulin-like growth factors and feto-placental growth. Placenta 2003;24: 803-812.

44 Laviola L, Perrini S, Belsanti G, Natalicchio A, Montrone C, Leonardini A, Vimercati A, Scioscia M, Selvaggi L, Giorgino R, Greco P, Giorgino F: Intrauterine growth restriction in humans is associated with abnormalities in placental insulin-like growth factor signalling. Endocrinology 2005;146: 1498-1505.

45 Mudgett JS, Ding J, Guh-Siesel L, Chartrain NA, Yang L, Gopal S, Shen MM: Essential role for p38alpha mitogen-activated protein kinase in placental angiogenesis. Proc Natl Acad Sci USA 2000;97:10454-10459.

46 Adams RH, Porras A, Alonso G, Jones M, Vintersten K, Panelli S, Valladare A, Perez L, Klein R, Nebreda AR: Essential role of p38alpha MAP kinase in placental but not embryonic cardiovascular development. Mol Cell 2000;6:109-116.

47 Desai J, Holt-Shore V, Torry RJ, Caudle MR, Torry DS: Signal transduction and biological function of placenta growth factor in primary human trophoblast. Biol Reprod 1999;60:887-892.

48 Hannke-Lohmann A, Pildner von Steinburg S, Dehne K, Benard V, Kolben M, Schmitt M, Lengyel E: Downregulation of a mitogen-activated protein kinase signalling pathway in the placentas of women with preeclampsia. Obstet Gynecol 2000;96:582-587.

49 Khong TY, De Wolf F, Robertson WB, Brosens I: Inadequate maternal vascular response to placentation in pregnancies complicated by pre-eclampsia and by small-for-gestational age infants. Br J Obstet Gynaecol 1986;93:1049-1059.

50 Kliman HJ, Nestler JE, Sermasi E, Sanger JM, Strauss JF: Purification, characterization, and in vitro differentiation of cytotrophoblasts from human term plancentae. Endocrinology 1986;118: $1567-1582$.

Stefano Cianfarani, MD

Rina Balducci Center of Pediatric Endocrinology

Department of Public Health and Cell Biology, Room E-178, Tor Vergata University,

Via Montpellier 1

IT-00133 Rome (Italy)

Tel. +3906 51002314, Fax +3906 5917415, E-Mail stefano.cianfarani@uniroma2.it 